\title{
CHARACTERIZATIONS OF Trichoderma sp. AND ITS EFFECT ON Ralstonia solanacearum OF TOBACCO SEEDLINGS
}

\author{
Sutarman $^{1}$, Ahmad Khafidh Jalaluddin ${ }^{1}$, Arrohmatus Syafaqoh Li'aini ${ }^{2}$, \& \\ Andriani Eko Prihatiningrum ${ }^{1}$
}

\author{
${ }^{1}$ Department of Agrotechnology, Faculty of Sains and Technology, Universitas Muhammadiyah Sidoarjo, Indonesia \\ J1. Raya Mojopahit 666B Sidoarjo East Java \\ ${ }^{2}$ Eka Karya Botanic Garden Indonesian Institute of Science, Indonesia \\ Candikuning Baturiti Bali 82191 \\ E-mail: sutarman@umsida.ac.id
}

Manuscript received: 20 May 2020. Revision accepted: 28 August 2020.

\begin{abstract}
Characterizations of Trichoderma sp. and its effect on Ralstonia solanacearum of tobacco seedlings. This study aims to determine the molecular-based characteristics of Trichoderma sp. Tc-Jjr-02 and its effect as a biocontrol agent in protecting tobacco seedlings against bacterial wilt caused by $R$. solanacearum. The characterization of biocontrol agents was based on morphological and molecular data's observation using microscope and the key of determination. The in vivo experiments was consist of five treatments: (1) inoculation of Trichoderma isolates at six hours before $R$. solanacearum inoculation, (2) inoculation of Trichoderma isolates at six hours after $R$. solanacearum inoculation (3) simultaneous inoculation of Trichoderma isolates and $R$. solanacearum, (4) inoculated only with $R$. solanacearum, and (5) without any inoculation. The experiment was repeated six times. Based on BLAST's analysis, the Tc-Jjr-02 sequence is in accordance with T. asperellum with $100 \%$ Query Cover. Inoculation of T. asperellum Tc-Jjr-02 at six hours before and after and simultaneously with pathogens providing protection for young tobacco plants by slowing down the time for the onset of blight by $100-162 \%$, reducing the symptom index by $56-63 \%$, and increasing the dry weight of plant biomass by $39-53 \%$ compared to tobacco seeds which were only inoculated with $R$. solanacearum.
\end{abstract}

Key words: bacterial wilt, characterization, Ralstonia solanacearum, Trichoderma sp. Tc-Jjr-02

\section{INTRODUCTION}

Tobacco has important role in the national economy as currently Indonesia is one of the biggest tobacco producers in the world (Raheem et al., 2016). The use as a cigarette however, is increasingly suppressed (Levy et al., 2017) and various alternative forms of substitution consumption continue to be developed (Farsalinos et al., 2016), especially for health and pharmaceutical industries (Daniel, 2011; Fauzantoro et al., 2017), as well as active ingredients for pesticides (Araka et al., 2016).

The quality and productivity of tobacco cultivation is largely determined by the success in protecting plants from damage due to environmental stress and destructive organisms. Ralstonia solanacearum is a bacterium that causes Tobacco bacterial wilt disease which is very detrimental to tobacco cultivation (Li et al., 2016). This bacterium can also damage various plants of the Solanaceae family including tomatoes (Huang et al., 2013) and potatoes (Kheirandish \& Harighi, 2015).
Moreover, it can even cause diseases in various important commodities in the world (Jiang et al., 2017).

To date, the control of tobacco plant diseases has always relied on chemical pesticides which often fail to overcome severe disease attacks (Li et al., 2014). Active ingredients of pesticides often cause disruption to the health of operators, develop pathogen resistance, and cause damage to non target organisms in plantations (Gava \& Pinto, 2016), in addition to the impact of toxic materials pollution on the environment (Widmer, 2014) as well as the threat of exposure to hazardous substances for the public in around plantations (Damalas \& Eleftherohorinos, 2011; Jallow et al., 2017).

Utilization of biological control agents is one of the efforts to protect plants against pathogens that have good prospects in the future. However, the application must accompanied by the provision of nutrients and compounds that can encourage plant growth, so that plants get protection both directly and indirectly in the form of induced systemic resistance. 
Trichoderma is a fungus that can be used as a biological controller and has the ability as a biofertilizer (Glare et al., 2012; Buysens et al., 2016). This fungus produces antibiotic, toxins, and enzymes that can inhibit pathogens (Pruksakorn et al., 2010; Chowdappa et al., 2013; Buysens et al., 2016), it could damage the cell walls (Yedidia et al., 2000) and degrade organic matter (Hu et al., 2015; Saravanakumar et al., 2016) of plant pathogenic fungi. The Trichoderma ability to produce extracellular compounds such as auxins and its derivatives (Vinale et al., 2014), make it a superior biofertilation agent that can guarantee the nutritional needs and growth of plants while reducing the use of synthetic pesticides (Hu et al., 2016).

The main character of Trichoderma as a biocontrol and biofertilizer is indispensable for the protection of plants, including seeds, seedlings and young tobacco plants. However, selection of Trichoderma types and isolates are needed to choose the one that can provide a positive response to tobacco plants in inducing resistance to pathogen. Understanding the characteristics of Trichoderma fungus that is effective in controlling one type and/or several types of plants is important for the practice of formulations, the procurement of biological agents for crop protection, and for the development of their applications. For this reason, it is necessary to identified Trichoderma species based on molecular markers to provide adequate information for other researchers and executives engaged in plant protection.

Trichoderma sp. Tc-Jjr-02 is isolates collection of the UMSIDA Microbiology Laboratory that proved to be effective in controlling plants that have close kinship with tobacco, such as tomatoes (Huang et al., 2013) and potatoes (Kheirandish \& Harighi 2015; Sutarman, 2019). This study aims to determine the molecular-based characteristics of Trichoderma sp. Tc-Jjr-02 and its effect as a biocontrol agent in protecting tobacco seedlings against bacterial wilt caused by $R$. solanacearum. Molecular characterization of biocontrol agents was also used in this experiment to provide additional information supporting the morphological character information.

\section{MATERIALS AND METHODS}

Research Site. This research was conducted at the Microbiology Laboratory and Greenhouse of the Departement of Agrotechnology, Faculty of Science and Technology and the Molecular Biology Laboratory of the Faculty of Health Sciences, Universitas Muhammadiyah Sidoarjo in March-July 2019.

\section{Morphology and Molecular Characterization of Biocontrol Agent.}

Morphological Observations. The two-week-old Trichoderma Tc-Jjr-02 isolate was propagated and placed on glass objects to be observed under a microscope at 400 times magnification. Microscopic structures to be observed were hyphal, phialid, conidiophores, and conidiaspore branches. The morphological characteristics then compared with the description and key of determination by Gams \& Bissett (2002).

DNA Isolation and Preparation. In total, $50 \mathrm{mg}$ of propagules containing Trichoderma sp. Tc-Jjr-02 was put into $200 \mu \mathrm{L}$ of $\mathrm{dH}_{2} \mathrm{O}$ in the BashingBead ${ }^{\mathrm{TM}}$ tube and added $750 \mu \mathrm{L}$ of BashingBead ${ }^{\mathrm{TM}}$ buffer (Zymo Research, USA). The suspension then centrifuged at $10,000 \times \mathrm{g}$ for $1 \mathrm{~min}$. The supernatant was then taken $(400 \mu \mathrm{L})$ and put into the Zymo-Spin ${ }^{\mathrm{TM}}$ III-F filter (Zymo Research, USA) and placed in a collection tube then centrifuge at $10,000 \times \mathrm{g}$ for $1 \mathrm{~min}$. The filtrate then added with $1200 \mu \mathrm{L}$ genomic lysis buffer (Zymo Research, USA). A total of $800 \mu \mathrm{L}$ of the mixture was transferred into the Zymo-Spin ${ }^{\mathrm{TM}}$ IICR column (Zymo Research, USA) with collection tube and centrifuge at $10,000 \times \mathrm{g}$ for $1 \mathrm{~min}$. Spill (flow through) was discharged until the liquid runs out. The mixture added with $200 \mu \mathrm{L}$ of DNA pre-wash buffer and put new collection tube, then centrifuged $10,000 \times \mathrm{g}$ for $1 \mathrm{~min}$. A total of $500 \mu \mathrm{L}$ g-DNA wash buffer was added to the Zymo-Spin ${ }^{\mathrm{TM}}$ IICR column (Zymo Research, USA) and centrifuged at $10,000 \times \mathrm{g}$ for $1 \mathrm{~min}$. Then the Zymo-Spin ${ }^{\mathrm{TM}}$ IICR column was transferred to a clean $1.5 \mathrm{~mL}$ microcentrifuge tube and $100 \mu \mathrm{L}$ DNA elution buffer was added directly to the center of the column and finally centrifuged at $10,000 \times \mathrm{g}$ for $30 \mathrm{~s}$ to elute the DNA.

Polymerase Chain Reaction. DNA amplification was performed on the Biorad T100 thermalcycler machine. The cycles used include pre-denaturation at $95^{\circ} \mathrm{C}$ for 5 min, denaturation at $95^{\circ} \mathrm{C}$ for $1 \mathrm{~min}$, annealing at $60^{\circ} \mathrm{C}$ for $1 \mathrm{~min}$, and primer extension at $72^{\circ} \mathrm{C}$ for $1 \mathrm{~min}$. A total of 40 cycles were carried out with one cycle of final elongation for $10 \mathrm{~min}$. The reaction used was 25 $\mu \mathrm{L}$ PCR mixture (Bioline), $1 \mu \mathrm{L}$ each of 10 pmol primer ITS 1 (5'-TCC GTA GGT GAA CCT GCG G-'3) and ITS 4 (5'-TCC TCC GCT TAT TGA TAT GC-3' (White 
et al., 1990; Fierer et al., 2005), $5 \mu \mathrm{L}$ DNA template, and $18 \mu \mathrm{L}$ sterile $\mathrm{ddH}_{2} \mathrm{O}$.

Sequencing and Phylogenetic Analysis. Sequencing was performed using Sanger sequencing, $50 \mu \mathrm{L}$ of the PCR product was sent to a commercial DNA sequencing service (1st Base; Singapore). Nucleotides were produced from sequencer machines (ABI 3730XL sequencers) and compared to GenBank using the Basic Local Alignment Search Tool (BLAST) program available at the National Center for Biotechnology Information (NCBI, 2020). Phylogenetic analyses were conducted in MEGA X (Kumar et al., 2018).

\section{Greenhouse Experiment.}

Isolates Preparation. Trichoderma sp. Tc-Jjr-02 isolate used in this experiment was the collection of Microbiology Laboratory at Universitas Muhammadiyah Sidoarjo. Trichoderma isolate was propagated in PDAchloramphenicol medium (Gil et al., 2009) with an incubation period of 14 days. After 14 days, the cultures of the isolate was harvested, crushed, and mixed with water to produce a suspension with a population density of $10^{8} \mathrm{cfu} \mathrm{mL}^{-1}$.

The pathogenic bacterial isolate of $R$. solanacearum that used in this study was a collection of the Balai Besar Perbenihan dan Proteksi Tanaman Perkebunan (BBPPTP) Surabaya, Directorate General of Plantations-Ministry of Agriculture, MojoagungJombang, East Java. Pathogenic bacterial isolate was propagated on NA media, after 4 days of incubation the culture was harvested and mixed with water to create an active spore suspension with population density of $10^{9} \mathrm{cfu} \mathrm{mL}^{-1}$. For application purposes, each suspensions was diluted with sterile water to $10^{7} \mathrm{cfu}$ $\mathrm{mL}^{-1}$ conidia of Tc-Jjr-02 isolates and $10^{8} \mathrm{cfu} \mathrm{mL}^{-1}$ active bacterial cells of $R$. solanacearum (Li et al., 2016). Each suspensions then stored in a $500 \mathrm{~mL}$ glass beaker; All isolation and propagation activities were done in aseptic conditions.

Planting Medium and Plant Variety. The soil that used as a planting medium was derived from land with a height of $\pm 8.0 \mathrm{~m}$ asl in Jiken Village, Tulangan District, Sidoarjo Regency, East Java Province with basic characteristics: $\mathrm{pH}\left(\mathrm{H}_{2} \mathrm{O}\right) 7.05, \mathrm{C}$-organic $0.56 \%, \mathrm{C} / \mathrm{N}$ ratio 14, CEC 29.64, and dusty clay texture. The soil was sterilized by autoclaving in $120^{\circ} \mathrm{C}$ at $1 \mathrm{~atm}$ for 30 $\min$.

In this experiment, Baleno variety of tobacco was used. This variety is usually planted in the dry season. Healthy seedlings were collected from planting tobacco seeds on sterile soil media for two months. The uniform and healthy seedlings showing no symptoms of necrosis, lesion, and/or other symptoms of the disease. About $30 \%$ of the root tip was cut using a sharp and sterile knife. Roots that have been cut off/injured were inserted into a suspension that contains biocontrol agent conidial suspensions and pathogenic bacterial cels or sterile water according to the desired treatment for $10 \mathrm{~min}$. After the roots dry, the seedlings were transferred in to a new sterile growing media. Furthermore, seedlings were maintained in a nursery condition by watering with sterile water in the planting medium to maintain humidity according to the needs of the growth of tobacco plant seeds.

Experimental Design. The experiment in this study was arranged in a completely randomized design (CRD) consisting of co-inoculation of Trichoderma isolate and $R$. solanacearum in various inoculation methods. The treatments were: (1) inoculation of Trichoderma isolate at six hours before $R$. solanacearum inoculation, (2) inoculation of Trichoderma isolate at six hours after $R$. solanacearum inoculation, (3) simultaneous inoculation of Trichoderma isolate and $R$. solanacearum, (4) inoculated only with $R$. solanacearum, and (5) without any inoculation. The treatments were repeated six times, so that 30 experimental units were studied.

The observed variables in this study were: (i) incubation periode of bacterial wilt (hours); (ii) the bacterial wilt symptom index at 4 and 8 days after inoculation (DAI) using the formula which was determined based on the criteria in Table 1 (modified from Tahir et al., 2017); and (iii) dry weight of seedling stover at 6 days after inoculation $(\mathrm{g})$.

Table 1. Scores and categories of symptoms of tobacco leaf seeddlings wilt disease

\begin{tabular}{cl}
\hline Score & \multicolumn{1}{c}{ Criteria for symptoms } \\
\hline 0 & There are no symptomatic/diseased plant parts \\
1 & Symptomatic plant parts withering: $1-25 \%$ or one withered leaf \\
2 & Symptomatic plant parts withering $25-50 \%$ or two withered leaves \\
3 & Symptomatic plant parts withering $50-75 \%$ or two to three withered leaves \\
\hline
\end{tabular}

Source: Tahir et al. (2017) 
Disease severity index was calculated using the following formula:

$$
\text { DSI }=\frac{\sum \mathrm{n}_{\mathrm{i}} \times \mathrm{v}_{\mathrm{i}}}{\mathrm{N} \times \mathrm{k}} \times 100 \%
$$

$$
\begin{aligned}
\text { DSI = } & \text { Disease severity index (\%), } \\
n_{\mathrm{i}}= & \text { Number of plants with a score of } \mathrm{i}, \\
\mathrm{v}_{\mathrm{i}}= & \text { Numerical value (score) of plants with } \\
& \text { appropriate symptoms (Table } 1), \\
\mathrm{N}= & \text { Number of plants observed per unit of } \\
& \text { experiment, } \\
\mathrm{k} \quad= & \text { Value highest score of symptoms. }
\end{aligned}
$$

Data Analysis. The data's results of experiments on biological agents applications were analyzed using analysis of variance (ANOVA) at $5 \%$ and $1 \%$ significance levels and if the results of the analysis of variance were significantly different $(p<0.05)$ and very significant $(\mathrm{p}<0.01)$, then the analysis was followed with the 5\% Honestly Significant Difference (Tukey test).

\section{RESULTS AND DISCUSSION}

\section{Observation of Morphology and Characterization} of Biocontrol Agents. Morphological observations of Trichoderma sp. Tc-Jjr-02 isolate in Figure 1 shows the appearance of colony and microscopic structures. The description of both macroscopic and microscopic characteristics were shown in Table 2.
The result of electrophoresis DNA sequences of Trichoderma sp. isolate Tc-Jjr-02 for the biocontrol agent is shown in Figure 2. The results of BLAST search (https://www.ncbi.nlm.nih.gov/) showed 100\% similarity with Trichoderma asperellum (isolate Tasum66, accession number MT102403.1) the dendrogram can be seen in Figure 3. It revealed that the Trichoderma sp. isolate Tc-Jjr-02 was placed in the same branch with refference strains of $T$. asperellum.

Homologous sequences obtained from the NCBI Gene Bank were reconstructed by MEGA 7 software (Kumar et al., 2018) with the Neighbor Joining method so that a phylogenetic tree was produced (Figure 3). A similar method was used by Anam et al. (2019) on the RM-28 isolate whose data was stored in NCBI with the accession number MK092975 and identified as T. asperellum. The morphological and molecular characteristics of the Tc-Jjr-02 isolate are similar and consistent with Trichoderma sp. isolate T1 (accession number GenBank LC158827, KU497722 and KU497723) (Baiyee et al., 2019) and with isolate TC01 (accession number GenBank MH752042 and MN813963) (Shang et al., 2020), each of which is based on a phylogenetic tree determined as T. asperellum.

The shape and dimensions of conidyspores and chlamydospores Tc-JJr-02 also have similarities with the $T$. asperellum VM 100 (KY412854) endophytic isolate on Vinca minor stem which is able to control R. solanacearum (Leylaie \& Zafari, 2018), and with

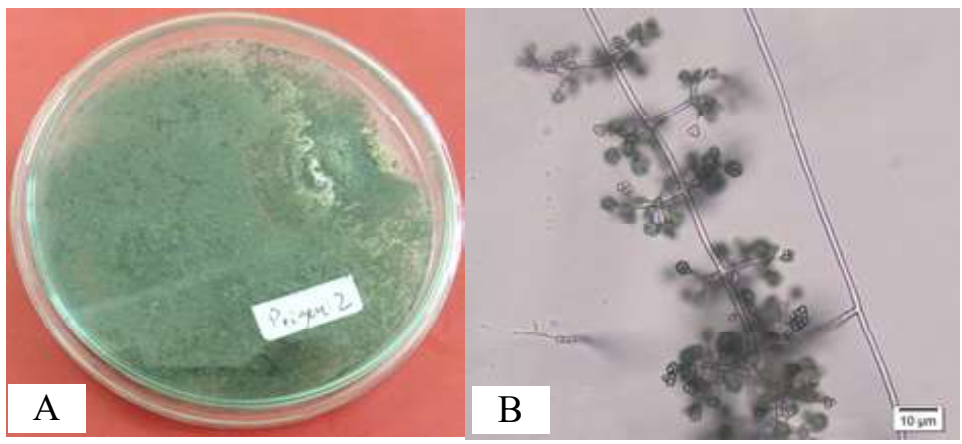

Figure 1. Trichoderma sp. Tc-Jjr-02 isolate. (A) Colony; (B) Microscopy structure

Table 2. Morphological description of Trichoderma sp. Tc-Jjr-02

\begin{tabular}{cl}
\hline Form & \multicolumn{1}{c}{ Descriptions } \\
\hline Colony (macroscopic) & $\begin{array}{l}\text { At the beginning of growth, the colonies appear to have green stools with white edges, } \\
\text { then the colonies appear green }\end{array}$ \\
Microscopic structures & $\begin{array}{l}\text { Hypha seeped to form elbows, hyaline conidiophore, shaped like a pyramid, upright } \\
\text { branched, and slippery wall, phialid shaped like a thick pumpkin with size 5-7 } \mu \mathrm{m} ; \\
\text { conidia are rather rounded or oval, slightly greenish color, size 2.5-3.5 } \mu \mathrm{m}\end{array}$ \\
\hline
\end{tabular}




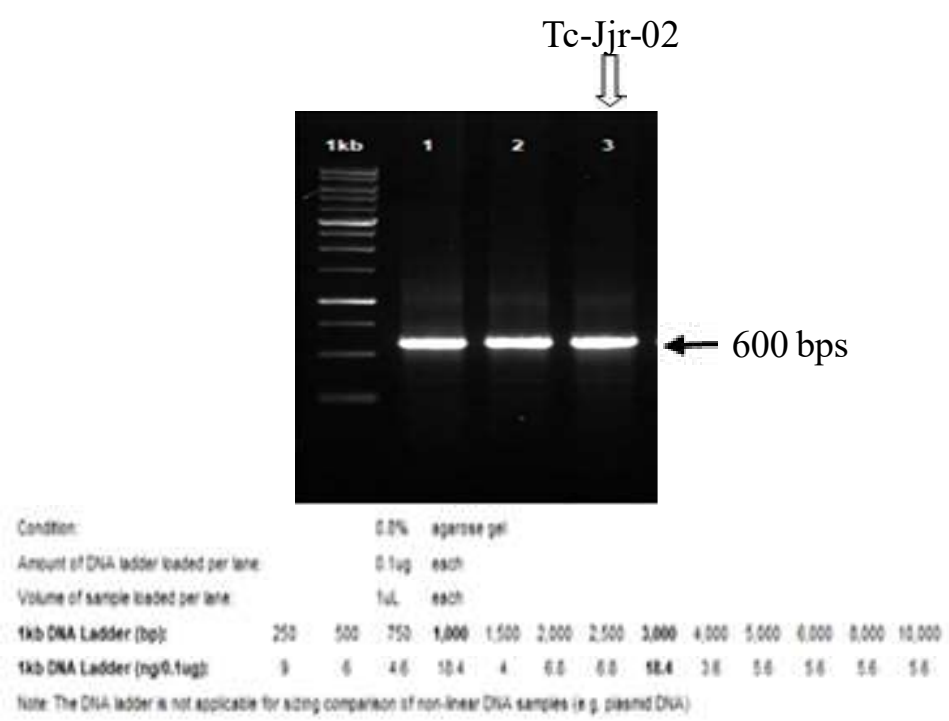

Figure 2. Electrophoresis of Trichoderma Tc-Jjr02 DNA fragments

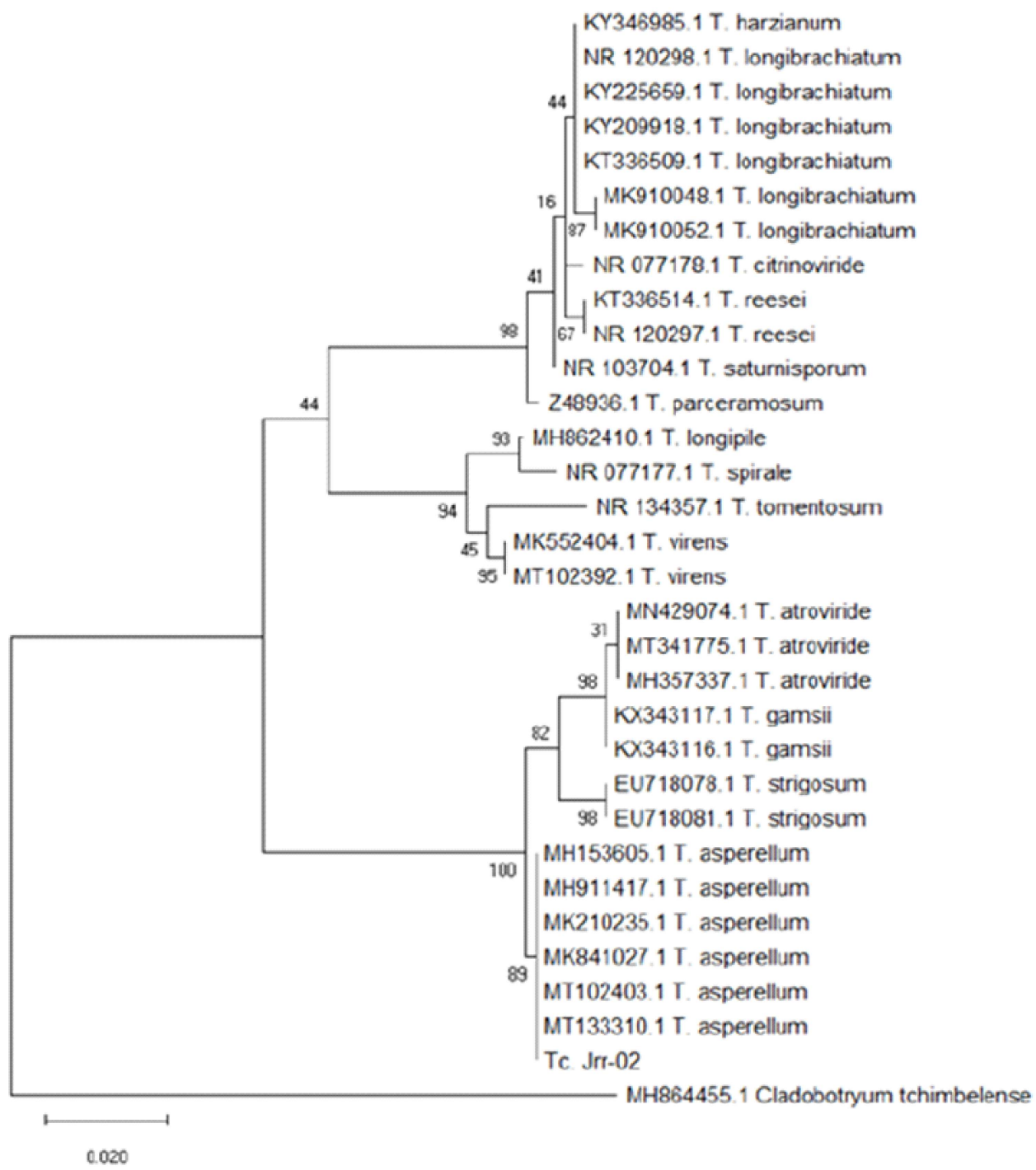

Figure 3. Phylogenetic tree of ITS region contructed with Neighbor Joining method on MegaX (Kumar et al., 2018) with 1000x bootstrap showing Trichoderma asperellum as the most predominant homolog of TcJjr-02 isolate. 
T. asperellum GDFS1009 isolate used by Karuppiah et al. (2019) in testing the control power of Fusarium granarium and its ability to promote wheat plant growth. Likewise, the dimensions of conidiospores and hyphal branching and the appearance of similar colonies between Tc-Jjr-02 and Trichoderma Ta1 and Ta2 isolates were also shown by Hewedy et al. (2020) based on the kinship analysis defined as T. asperellum.

Greenhouse Experiment. The analysis of variance showed that Trichoderma influenced the initial emergence of wilting symptoms in tobacco seedlings $(p<0.01)$ (Table 3). The appearance of each tobacco plant seedling at 96 hours after inoculation was shown in Figure 4. It also showed that Trichoderma sp. influenced on the bacterial wilt symptom index of tobacco seedlings $(\mathrm{p}<0.01)$. The mean index of disease symptoms at 4 and 8 DAI was presented in Table 4 . The analysis results showed that Trichoderma sp. influenced on the dry weight of stover tobacco seedlings $(p<0.01)$. The average dry weight of stover tobacco seedlings was presented in Table 5.

Overall, Trichoderma sp. inoculation at 6 hours before pathogen innoculation, six hours after pathogen innoculation, as well as simultaneous innoculation with pathogen could: (i) slowing down the time to onset of blight symptoms 100,162 , and $154 \%$, (ii) suppressing the symptom index of 63,56 , and $56 \%$, and (iii)

Table 3. Mean effects of Trichoderma sp. Tc-Jjr-02 on the initial appearance of symptoms of tobacco bacterial wilt

Treatment

Trichoderma inoculation 6 hours before inoculation of pathogen

Trichoderma inoculation 6 hours after inoculation of pathogen

Trichoderma inoculation together with pathogen inoculation

Only pathogen inoculation

Without Trichoderma and pathogen inoculation
Time at which the initial symptoms appear (hours)

The mean followed by different letters shows significantly different effect (HSD; $\alpha=0.05$ )

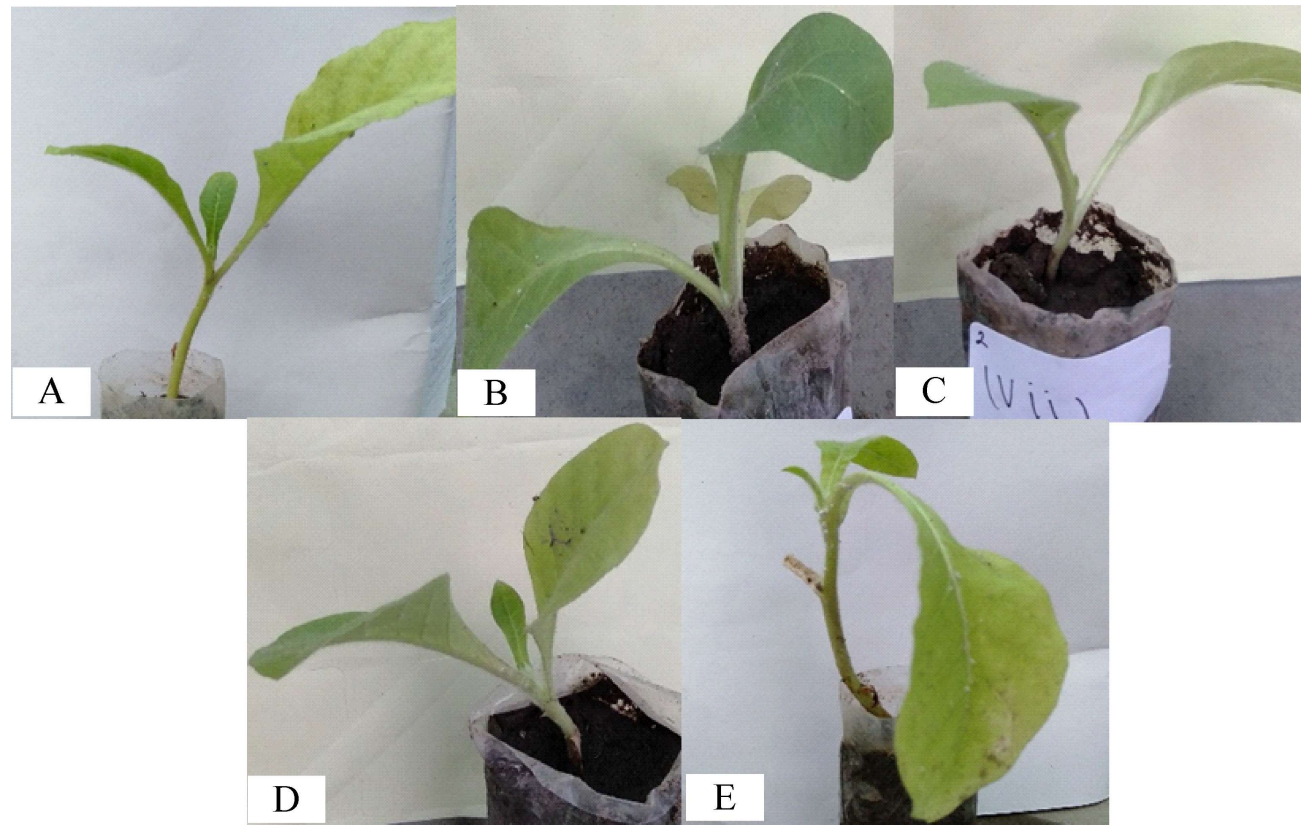

Figure 4. Appearance of tobacco seedlings at 90 hours after inoculation. (A) Trichoderma sp. inoculation 6 hours before inoculation of pathogens; (B) Trichoderma sp. inoculation 6 hours after inoculation of pathogens; (C) Trichoderma sp. inoculation together with pathogens; (D) Only inoculated pathogens; (E) Without inoculation. 
increasing the biomass dry weight of tobacco seedlings was 39,42 , and $53 \%$ compared to tobacco seedlings which were only inoculated with $R$. solanacearum.

Plants that were not inoculated with pathogens and Trichoderma sp. appeared to be wilt starting from 92 hours after inoculation (Table 3, Figure 4) with symptom indices of 15.63 and 18.75 , respectively at 4 and 8 DAI (Table 4). The rather withering symptoms were not plant infections, but the seedlings response to stressful environmental temperatures. The temperature and humidity in the greenhouse in this experiment (22$30^{\circ} \mathrm{C}$ and $70-80 \%$ ) could cause symptoms of wilting in post-overspine tobacco seedlings in all treatments; and could accelerate the increase in intensity of wilting symptoms (Li et al., 2017). In hot conditions throughout the day, tomato plants were usually more susceptible to infection by pathogens as indicated by the appearance of leaves that look wilted (EMPPO, 2004).

Fungi released secondary metabolites such as peptaibols and harzianolides (Zeilinger et al., 2016), acid phosphatase that play a role in phosphate solubilization (Zhao et al., 2017) and various other active secondary metabolites to the rhizosphere that promote root branching and nutrient absorption for plants (MartínezMedina et al., 2014; López-Bucio et al., 2015). The growth and development of root was strongly influenced by the availability of hormones (Giehl \& von Wirén, 2014). Trichoderma could increase lateral root development and encourage plant growth (Rubio et al., 2014), increasing shoot and root dry weight as well as chlorophyll content (Colla et al., 2015).

In the treatment that was inoculated only with $R$. solanacearum, wilting quickly appeared with the highest average disease index $(61 \%)$. Withered occured due to a blockage in the root vessel transport network by bacterial cells and polysaccharides (Mutimawurugo et al., 2019) which could threaten the plant to death. This pathogenic bacterial infection could increase root exudate in the form of various organic acids which can create a rhizosphere environment that was less favorable for plants (Li et al., 2018). R. solanacearum produced various enzymes effector outside its cells and in the plant cells which were indicated by the activity of acetyltransferases, phosphatases, and proteases in the framework of plant infection (Wei et al., 2017). With the intensity of attack symptoms that exceeded $50 \%$, the Baleno variety of tobacco could be categorized as susceptible to bacterial wilt diseases (Laeshita \& Arwiyanto, 2017). In line with this study, T. harzianum which was formulated as a biofertilizer made from compost carriers, was able to suppress the tobacco seedlings disease index by $26.8 \%$, while in the control the seedling disease index could reach $68.2 \%$, (Yuan et al., 2016). Another study showed that, until the plants were ready to harvest, no application of biocontrol agents could raises the incidence of bacterial wilt disease up to

Table 4. Mean effects of Trichoderma sp. Tc-Jjr-02 on the index of symptoms of tobacco bacterial wilt

\begin{tabular}{lcc}
\hline \multicolumn{1}{c}{ Tretament } & \multicolumn{2}{c}{ Disease symptoms index } \\
\cline { 2 - 4 } & 4 DAI & 8 DAI \\
\hline Trichoderma inoculation 6 hours before inoculation of pathogen & $21.88 \pm 3.42 \mathrm{ab}$ & $22.92 \pm 3.23 \mathrm{ab}$ \\
Trichoderma inoculation 6 hours after inoculation of pathogen & $20.83 \pm 3.23 \mathrm{ab}$ & $27.08 \pm 3.23 \mathrm{~b}$ \\
Trichoderma inoculation together with pathogen inoculation & $25.00 \pm 5.59 \mathrm{~b}$ & $27.08 \pm 3.23 \mathrm{~b}$ \\
Only pathogen inoculation & $42.71 \pm 2.55 \mathrm{c}$ & $61.46 \pm 4.70 \mathrm{c}$ \\
Without Trichoderma and pathogen inoculation & $15.63 \pm 3.42 \mathrm{a}$ & $17.71 \pm 2.55 \mathrm{a}$ \\
\hline
\end{tabular}

The mean followed by different letters in the same column shows significantly different effect (HSD; $\alpha=0.05$ ).

Table 5. Mean effects of Trichoderma sp. Tc-Jjr-02 on the dry weight of the tobacco seedlings stover

\begin{tabular}{lr}
\hline \multicolumn{1}{c}{ Tretament } & $\begin{array}{c}\text { Weight of dry stover } \\
(\mathrm{g})\end{array}$ \\
\hline Trichoderma inoculation 6 hours before inoculation of pathogen & $10.33 \pm 2.42 \mathrm{a}$ \\
Trichoderma inoculation 6 hours after inoculation of pathogen & $10.50 \pm 2.51 \mathrm{a}$ \\
Trichoderma inoculation together with pathogen inoculation & $11.33 \pm 1.97 \mathrm{a}$ \\
Only pathogen inoculation & $7.42 \pm 1.56 \mathrm{~b}$ \\
Without Trichoderma and pathogen inoculation & $12.83 \pm 2.32 \mathrm{a}$ \\
\hline
\end{tabular}

The mean followed by different letters shows significantly different effect (HSD; $\alpha=0.05$ ) 
62.67-62.89\% (Wu et al., 2020). Susceptibility of tobacco seedlings showed that plants lack the ability to inhibit enzyme activity in the infection process (Khan et al., 2016).

Trichoderma does not interfere with the stability of bacterial cells, but the enzyme chitinase produces by bacteria could disturb the stability of the fungal cell wall (Chowdappa et al., 2013). The chitinase enzyme could trigger Trichoderma to defense itself by realizing antimicrobial compounds such as 6-Pentyl-a-pyrone, harzianolide harzianopyridone (Vinale et al., 2008) phenyl ammonia lyase (PAL), peroxidase, polyphenol oxidase, lipoxygenase (Fan et al., 2011) related to the activity of regulating plant growth and plant resistance to pathogens (Singh et al., 2018).

Trichoderma use most of the organic material from cells that die as substrate for its activities ( $\mathrm{Hu}$ et al., 2015; Sutarman et al., 2018). Decomposition of organic matter by Trichoderma will contribute as nutrients for plant to grow (He et al., 2019) which reflected by stover dry weights and root dry weights (Table 5). In treatments using Trichoderma, the root weights were 10.33-11.33 g. This result were not significantly different from the dry weight of stover seedlings that were not inoculated by any microorganism.

The treatment that inoculated with Trichoderma sp. showed a low symptom index, which is $22.92-27.08$ at 6 DAI. In the treatment of Trichoderma sp. application 6 hours before the pathogen inoculation, the disease index did not differ significantly from the treatment without any inoculation. This fact shows that this fungus possesses the ability to compete in the use of space (Lu et al., 2016).

Trichoderma has the ability as an endophyte which is shown by its protective ability in plant tissue (Abdulmyanova et al., 2015) and the anti-microbial compounds it produces (Zeilinger et al., 2016) making it able to suppress pathogenic bacteria as shown by T. asperellum against $R$. solanacearum in Vinca minor plants (Leylaie \& Zafari, 2018) and T. asperellum isolate Tc-Jjr-02 on $R$. solanacearum on tobacco seedlings in this experiment. The suppression by biological agents will have an effect on decreasing the density of pathogenic bacterial cells according to Wei et al. (2015) will have an effect on decreasing the intensity and incidence of plant diseases.

The similarity of the Tc-Jjr-02 isolate nucleotide sequence with $T$. asperellum is also shown by the similar role in promoting plant biomass. Tc-Jjr-02 was able to increase the biomass of tobacco seedlings, also similar to $T$. asperellum isolate RM-28 which increases sorghum-sudangrass seedling biomass (Anam et al.,
2019). The characteristics of Tc-Jjr-02 in enhancing plant growth and resilience were represented by the suppression of a similar symptom index shown by T. asperellum TI which induces plant resilience to leaf spot fungi in lettuce (Baiyee et al., 2019) and T. asperellum TC01 on Camellia sinensis seedlings (Shang et al., 2020), and as a control for stem rot in carnation (Vinodkumar et al., 2017).

Information on the characteristics of Trichoderma sp. both morphologically and molecularly is important as a consideration in controlling bacterial wilt caused by $R$. solanacearum, considering that, this pathogen is also proven to cause severe attacks not only on tobacco plants but also on tomato and potato plants (Gutarra et al., 2017).

\section{CONCLUSION}

The molecular identification results showed that Trichoderma sp. Tc-Jjr-02 is Trichoderma asperellum. This fungus is influential in providing protection for young tobacco plants by slowing down the initial appearance of blight symptoms by $100-162 \%$, reducing the symptom index of 56-63\%, and increasing the dry weight of plant biomass $39-53 \%$ compared to tobacco seeds which are only inoculated with Ralstonia solanacearum. Inoculation of T. asperellum Tc-Jjr-02 at six hours before and after and simultaneously with pathogens were not significantly different in response to plant resistance.

\section{ACKNOWLEDGMENTS}

The author would like to thanked the Ministry of Research and Technology for the 2019-2020 Higher Education Applied Research (PTUPT) grant that he gave so that this article can be compiled.

\section{REFERENCES}

Abdulmyanova LI, Teomashko NN, Terentyeva EO, Ruzieva DM, Sattarova RS, Azimova SS, \& Gulyamova TG. 2015. Cytotoxic activity of fungal endophytes from Vinca. Int. J. Curr. Microbiol. App. Sci. 4(7): 321-329.

Anam GB, Reddy MS, \& Ahn YH. 2019. Characterization of Trichoderma asperellum RM-28 for its sodic/saline-alkali tolerance and plant growth promoting activities to alleviate toxicity of red mud. Sci. Total Environ. 662: 462-469. 
Araka GO, Ochora J, \& Wakhisi J. 2016. Larvicidal efficacy of crude essential oil (leaf extracts) of pyrethrum (Chrysanthemum: Compositae), Eucalyptus camaldulensis Sm (Myrtaceae) and Nicotiana tabaccum (Tobacco L.) (Solanaceace) against third instar larvae of the malaria vector Anopheles gambiae s.s. Giles (Diptera: Culicidae). Int. J. Sci. Res. 5(3): 370375.

Baiyee B, Ito S, \& Sunpapao A. 2019. Trichoderma asperellum $\mathrm{T} 1$ mediated antifungal activity and induced defense response against leaf spot fungi in lettuce (Lactuca sativa L.). Physiol. Mol. Plant Pathol. 106: 96-101.

Buysens C, César V, Ferrais F, de Boulois HD \& Declerck S. 2016. Inoculation of Medicago sativa cover crop with Rhizophagus irregularis and Trichoderma harzianum increases the yield of subsequently-grown potato under low nutrient conditions. Appl. Soil Ecol. 105: 137-143.

Chowdappa P, Kumar SPM, Lakshmi MJ, \& Upreti KK. 2013. Growth stimulation and induction of systemic resistance in tomato against early and late blight by Bacillus subtilis OTPB1 or Trichoderma harzianum OTPB3. Biol. Control. 65(1): 109-117.

Colla G, Rouphael Y, Mattia ED, El-Nakhel C, \& Cardarelli M. 2015. Co-inoculation of Glomus intraradices and Trichoderma atroviride acts as abiostimulant to promote growth, yield and nutrient uptake of vegetable crops. J. Sci. Food Agric. 95(8): 1706-1715.

Damalas CA \& Eleftherohorinos IG. 2011. Pesticide exposure, safety issues, and risk assessment indicators. Int. J. Environ. Res. Public Health. 8(5): 1402-1419.

Daniel H. 2011. Benefits of tobacco. http:// benefitof.net/benefits-of-tobacco/. Accessed on 24 April 2020.

[EMPPO] European and Mediterranean Plant Protection Organization. 2004. Diagnostic protocols for regulated pests: Ralstonia solanacearum. Bulletin OEPP/EPPO Bulletin. 34(2): 173-178.

Fan H, Song B, Bhadury PS, Jin L, Hu D, \& Yang S. 2011. Antiviral activity and mechanism of action of novel thiourea containing chiral phosphonate on Tobacco Mosaic Virus. Int. J. Mol. Sci. 12(7): 4522-4535.

Farsalinos KE, Poulas K, Voudris V, \& Le Houezec J. 2016. Electronic cigarette use in the European Union: analysis of a representative sample of 27 460 Europeans from 28 countries. Addiction. 111(11): 2032-2040.

Fauzantoro A, Muharam Y, \& Gozan M. 2017. Improvement of nicotine yield by ethanolic heat reflux extraction of Nicotiana tabacum var. virginia origin of Ponorogo. Int. J. Appl. Eng. Res. 12(23): 13891-13897.

Fierer N, Jackson JA, Vilgalys R, \& Jackson RB. 2005. Assessment of soil microbial community structure by use of taxon-specific quantitative PCR assays. Appl. \& Environ. Microb. 71(7): 4117-4120.

Gams W \& Bissett J. 2002. Morphology and identification of Trichoderma. In: Kubicek CP \& Harman GE (Eds.). Trichoderma and Gliocladium, Volume 1: Basic Biology, Taxonomy and Genetics. pp. 3-34. Taylor \& Francis Ltd. London.

Gava CAT \& Pinto JM. 2016. Biocontrol of melon wilt caused by Fusarium oxysporum Schlect f. sp. melonis using seed treatment with Trichoderma spp. and liquid compost. Biol. Control. 97: 1320.

Giehl RFH \& von Wirén N. 2014. Root nutrient foraging. Plant Physiol. 166(2): 509-517.

Glare T, Caradus J, Gelernter W, Jackson T, Keyhani N, Köhl J, Marrone P, Morin L, \& Stewart A. 2012. Have biopesticides come of age? Trends Biotechnol. 30(5): 250-258.

Gil SV, Pastor S, \& March GJ. 2009. Quantitative isolation of biocontrol agents Trichoderma spp. Gliocladium spp. and Actinomycetes from soil with culture media. Microbiol. Res. 164(2): 196205.

Gutarra L, Herrera J, Fernandez E, Kreuze J, \& Lindqvist-Kreuze H. 2017. Diversity, pathogenicity, and current occurrence of bacterial wilt bacterium Ralstonia solanacearum in Peru. Front. Plant Sci. 8: 1221.

He A, Liu J, Wang X, Zhang Q, Song W, \& Che J. 2019. Soil application of Trichoderma asperellum GDFS1009 granules promotes growth and 
resistance to Fusarium graminearum in maize. J. Integr. Agric. 18(3): 599-606.

Hewedy OA, Lateif KSA, Seleiman MF, Shami A, Albarakaty FM, \& El-Meihy RM. 2020. Phylogenetic diversity of Trichoderma strains and their antagonistic potential against soilborne pathogens under stress conditions. Biology. 9(8): 189.

Hu X, Roberts DP, Xie L, Yu C, Li Y, Qin L, Hu L, Zhang Y, \& Liao X. 2016. Use of formulated Trichoderma sp. Tri-1 in combination with reduced rates of chemical pesticide for control of Sclerotinia sclerotiorium on oilseed rape. Crop Prot. 79: 124-127.

Hu X, Roberts DP, Xie L, Maul JE, Yu C, Li Y, Zhang Y, Qin L, \& Liao X. 2015. Components of a riceoilseed rape production system augmented with Trichoderma sp. Tri-1 control Sclerotinia sclerotiorum on oilseed rape. Phytopathology. 105(10): 1325-1333.

Huang J, Wei Z, Tan S, Mei X, Yin S, Shen Q, \& Xu Y. 2013. The rhizosphere soil of diseased tomato plants as a source for novel microorganisms to control bacterial wilt. Appl. Soil Ecol. 72: 7984.

Jallow MFA, Awadh DG, Albaho MS, Devi VY, \& Thomas BM. 2017. Pesticide knowledge and safety practices among farm workers in Kuwait: results of a survey. Int. J. Environ. Res. Public Health. 14(4): 340.

Jiang G, Wei Z, Xu J, Chen H, Zhang Y, She X, Macho AP, Ding W, \& Liao B. 2017. Bacterial wilt in China: history, current status, and future perspectives. Front. Plant Sci. 8: 1549.

Karuppiah V, Sun J, Li T, Vallikkannu M, \& Chen J. 2019. Co-cultivation of Trichoderma asperellum GDFS1009 and Bacillus amyloliquefaciens 1841 causes differential gene expression and improvement in the wheat growth and biocontrol activity. Front. Microbiol. 10: 1068.

Khan M, Subramaniam R, \& Desveaux D. 2016. Of guards, decoys, baits and traps: pathogen perception in plants by type III effector sensors. Curr. Opin. Microbiol. 29: 49-55.

Kheirandish Z \& Harighi B. 2015. Evaluation of bacterial antagonists of Ralstonia solanacearum, causal agent of bacterial wilt of potato. Biol. Control. 86: 14-19.
Kumar S, Stecher G, Li M, Knyaz C, \& Tamura K. 2018. MEGA X: Molecular evolutionary genetics analysis across computing platforms. Mol. Biol. Evol. 35(6): 1547-1549.

Laeshita P \& Arwiyanto T. 2017. Resistance test of several tomato varieties to bacterial wilt diseases caused by Ralstonia solanacearum. Jurnal Perlindungan Tanaman Indonesia. 21(1): 5153.

Levy DT, Borland R, Lindblom EN, Goniewicz ML, Meza R, Holford TR, Yuan Z, Luo Y, O’Connor RJ, Niaura R, \& Abrams DB. 2017. Potential deaths averted in USA by replacing cigarettes with e-cigarettes. Tob Control. 27(1): 18-25.

Leylaie S \& Zafari D. 2018. Antiproliferative and antimicrobial activities of secondary metabolites and phylogenetic study of endophytic Trichoderma species from Vinca plants. Front. Microbiol. 9: 1484.

Li C, Yu J, Gan L, Sun J, Wang C, Wang Q, Chen S, \& Yang Y. 2018. Effects of tobacco pathogens and their antagonistic bacteria on tobacco root exudates. Open J. Appl. Sci. 8: 518-531.

Li L, Feng X, Tang M, Hao W, Han Y, Zhang G, \& Wan S. 2014. Antibacterial activity of Lansiumamide $\mathrm{B}$ to tobacco bacterial wilt (Ralstonia solanacearum). Microbiol. Res. 169(7-8): 522526.

Li X, Liu Y, Cai L, Zhang H, Shi J, \& Yuan Y. 2017. Factors affecting the virulence of Ralstonia solanacearum and its colonization on tobacco roots. Plant Pathol. 66(8): 1345-1356.

Li Y, Feng J, Liu H, Wang L, Hsiang T, Li X, \& Huang J. 2016. Genetic diversity and pathogenicity of Ralstonia solanacearum causing tobacco bacterial wilt in China. Plant Dis. 100(7): 12881296.

López-Bucio J, Pelagio-Flores R, \& Herrera-Estrella A. 2015. Trichoderma as biostimulant: exploiting the multilevel properties of a plant beneficial fungus. Sci. Hortic. 196: 109-123.

Lu Y, Rao S, Huang F, Cai Y, Wang G, \& Cai K. 2016. Effects of biochar amendment on tomato bacterial wilt resistance and soil microbial amount and activity. Int. J. Agron. 2016: 2938282.

[NCBI] National Center for Biotechnology Infromation. 2020. Basic Logical Alignment Search Tool. http:/ 
/www.ncbi.nlm.nih.gov/BLAST. Accessed on 1 February 2020.

Martínez-Medina A, Alguacil MDM, Pascual JA, \& Van Wees SCM. 2014. Phytohormone profiles induced by Trichoderma isolates correspond with their biocontrol and plant growth-promoting activity on melon plants. J. Chem. Ecol. 40(7): 804-815.

Mutimawurugo MC, Wagara IN, Muhinyuza JB, \& Ogweno JO. 2019. Virulence and characterization of isolates of potato bacterial wilt caused by Ralstonia solanacearum (Smith) in Rwanda. Afr. J. Agric. Res. 14(6): 311-320.

Pruksakorn P, Arai M, Kotoku N, Vilchèze C, Baughn AD, Moodley P, Jacobs WR Jr, \& Kobayashi M. 2010. Trichoderins, novel aminolipopeptides from a marine sponge-derived Trichoderma sp., are active against dormant mycobacteria. Bioorg. Bioorganic Med. Chem. Lett. 20(12): 36583663.

Raheem A, Khan N, \& Ali S. 2016. Influence of fungicide on post emergence of damping-off in tobacco (Nicotiana tobacum L.) nursery. Int. J. Cur. Res. 8(7): 34624-34629.

Rubio MB, Quijada NM, Pérez E, Domínguez S, Monte E, \& Hermosa R. 2014. Identifying beneficial qualities of Trichoderma parareesei for plants. Appl. Environ. Microbiol. 80(6): 1864-1873.

Saravanakumar K, Yu C, Dou K, Wang M, Li Y, \& Chen J. 2016. Synergistic effect of Trichodermaderived antifungal metabolites and cell wall degrading enzymes on enhanced biocontrol of Fusarium oxysporum f. sp. cucumerinum. Biol. Control. 94: 37-46.

Shang J, Liu B, \& Xu Z. 2020. Efficacy of Trichoderma asperellum TC01 against anthracnose and growth promotion of Camellia sinensis seedlings. Biol. Control. 143: 104205.

Singh A, Shukla N, Kabadwal BC, Tewari AK, \& Kumar J. 2018. Review on plant-Trichodermapathogen interaction. Int. J. Curr. Microbiol. App. Sci. 7(2): 2382-2397.

Sutarman, Prihatiningrum AE, Sukarno A, \& Miftahurrohmat A. 2018. Initial growth response of shallot on Trichoderma formulated in oyster mushroom cultivation waste. IOP Conf. Ser.: Materials Sci. Eng. 420: 012064.
Sutarman. 2019. Application of Trichoderma harzianum as soil treatment and additional treatment for control of potato diseases. J. Agric. Sci. 2(2): 139-150.

Tahir HAS, Gu Q, Wu H, Niu Y, Huo R, \& Gao X. 2017. Bacillus volatiles adversely affect the physiology and ultra-structure of Ralstonia solanacearum and induce systemic resistance in tobacco against bacterial wilt. Sci. Rep. 7: 40481.

Vinale F, Sivasithamparam K, Ghisalberti EL, Marra R, Woo LW, \& Lorito M. 2008. Trichoderma-plantpathogen interactions. Soil Biol. Biochem.40(1): $1-10$.

Vinale F, Sivasithamparam K, Ghisalberti EL, Woo SL, Nigro M, Marra R, Lombardi N, Pascale A, Ruocco M, Lanzuise S, Manganiello G, \& Lorito M. 2014. Trichoderma secondary metabolites active on plants and fungal pathogens. Open Mycol. J. 8: 127-139.

Vinodkumar S, Indumathi T, \& Nakkeeran S. 2017. Trichoderma asperellum (NVTA2) as a potential antagonist for the management of stem rot in carnation under protected cultivation. Biol. Control. 113: 58-64.

Wei Y, Sang Y, \& Macho AP. 2017. The Ralstonia solanacearum Type III effector RipAY is phosphorylated in plant cells to modulate Its enzymatic activity. Front. Plant Sci. 8: 1899.

Wei Z, Huang JF, Hu J, Gu YA, Yang CL, Mei XL, Shen $\mathrm{QR}, \mathrm{Xu} \mathrm{YC}$, \& Friman VP. 2015. Altering transplantation time to avoid periods of high temperature can efficiently reduce bacterial wilt disease incidence with tomato. PLOS ONE. 10(10): e0139313.

White TJ, Bruns T, Lee S, \& Taylor J. 1990. Amplification and direct sequencing of fungal ribosomal RNA genes for phylogenetics. In: Innis MA, Gelfand DH, Sninsky JJ, \& White TJ (Eds.). PCR Protocols: a guide to Methods and Applications. pp. 315-322. Academic Press, New York.

Widmer TL. 2014. Screening Trichoderma species for biological control activity against Phytophthora ramorum in soil. Biol. Control. 79: 43-48.

Wu X, Li H, Wang Y, \& Zhang X. 2020. Effects of bioorganic fertiliser fortified by Bacillus cereus QJ- 
1 on tobacco bacterial wilt control and soil quality improvement. Biocontrol Sci. Technol. 30(4): 351-359.

Yedidia I, Benhamou N, Kapulnik Y, \& Chet I. 2000. Induction and accumulation of PR proteins activity during early stages of root colonization by the mycoparasite Trichoderma harzianum strain T203. Plant Physiol. Biochem. 38(11): 863-873.

Yuan S, Li M, Fang Z, Liu Y, Shi W, Pan B, Wu K, Shi J, Shen B, \& Shen Q. 2016. Biological control of tobacco bacterial wilt using Trichoderma harzianum amended bioorganic fertilizer and the arbuscular mycorrhizal fungi Glomus mosseae. Biol. Control. 92: 164-171.

Zeilinger S, Gruber S, Bansal R, \& Mukherjee PK. 2016. Secondary metabolism in Trichoderma-chemistry meets genomics. Fungal Biol. Rev. 30(2): 7490 .

Zhao L, Liu Q, Zhang Y, Cui Q, \& Liang Y. 2017. Effect of acid phosphatase produced by Trichoderma asperellum Q1 on growth of Arabidopsis under salt stress. J. Integr. Agric. 16(6): 1341-1346. 